\title{
Effects of acute and chronic relaxin- 3 on food intake and energy expenditure in rats
}

\author{
B.M.C. McGOWAN, S.A. STANLEY, K.L. SMITH, J.S. MINNION, J. DONOVAN \\ E.L. THOMPSON, M. PATTERSON, M.M. CONNOLLY, C.R. ABBOTT, C.J. \\ SMALL, J.V. GARDINER, M.A. GHATEI \& S.R. BLOOM.
}

Department of Metabolic Medicine, Faculty of Medicine, Imperial College, $6^{\text {th }}$ Floor Commonwealth Building, Hammersmith Hospital, Du Cane Road, London W12 ONN, UK.

Address for correspondence and reprint requests: Stephen Bloom, Department of Metabolic Medicine, Imperial College, Hammersmith Campus, $6^{\text {th }}$ Floor Commonwealth Building, Du Cane Road, London W12 0NN, UK.

Tel: 00442083833242 Fax: 00442083833142

E-mail: s.bloom@imperial.ac.uk 


\section{Abstract}

The effects of acute and repeated intraparaventricular (iPVN) administration of human relaxin-3 (H3) were examined on food intake, energy expenditure, and the hypothalamic-pituitary thyroid axis in male Wistar rats. An acute high dose iPVN injection of $\mathrm{H} 3$ significantly increased food intake 1 hour post-administration $[0.4 \pm$ $0.1 \mathrm{~g}$ (vehicle) vs $1.6 \pm 0.5 \mathrm{~g}(180 \mathrm{pmol} \mathrm{H} 3), 2.4 \pm 0.5 \mathrm{~g}(540 \mathrm{pmol} \mathrm{H} 3)$ and $2.2 \pm 0.5 \mathrm{~g}$ (1620pmol H3), $\mathrm{p}<0.05$ for all doses vs vehicle]. Repeated iPVN H3 injection (180pmol/twice a day for 7 days) significantly increased cumulative food intake in ad libitum fed animals compared with vehicle [211.8 $\pm 7.1 \mathrm{~g}$ (vehicle) vs $261.6 \pm 6.7 \mathrm{~g}$ (ad libitum fed H3), $\mathrm{p}<0.05]$. Plasma leptin was increased in the H3 ad libitum fed group. Plasma thyroid stimulating hormone was significantly decreased after acute and repeated administration of $\mathrm{H} 3$. These data suggest $\mathrm{H} 3$ may play a role in longterm control of food intake.

Key words: relaxin-3, GPCR135 receptor, appetite, adiposity, energy expenditure 


\section{Introduction}

Relaxin-3 (INSL 7) is a recently identified peptide member of the insulin superfamily, typified by the presence of an A and B chain linked by inter- and intrachain disulphide bonds [1]. Like insulin, the intervening $\mathrm{C}$ peptide chain of relaxin-3 is removed by proteolytic processing. The relaxin-3 gene has been identified in humans (H3) [2], mice (M3) [2] and rats (R3) [3], and the gene products are highly homologous. R3 and M3 mRNA expression is localized to the nucleus incertus (NI) of the brainstem [3], a small nucleus in the central gray of the median dorsal pons near the fourth ventricle with projections to many hypothalamic nuclei. Relaxin-3 immunoreactive fibers project extensively to hypothalamic areas, including the lateral hypothalamic area, the arcuate (ARC) and paraventricular nuclei (PVN) [4; 5].

Relaxin-3 is the cognate ligand for two previously orphan G-protein-coupled receptors, GPCR135 and GPCR142 [6; 7]. GPCR142 is a pseudogene in the rat and thus not expressed, but GPCR135 mRNA is highly expressed in the rat brain, particularly the PVN and the supraoptic nucleus (SON) [6; 8]. In addition, relaxin-3 binds to the LGR7 receptor, which also binds relaxin-1 peptide with high affinity and, although it is primarily distributed in reproductive tissues, it is also present in the CNS [9-11].

We have recently shown for the first time, that acute intracerebroventricular and iPVN administration of low dose $\mathrm{H} 3$ stimulates feeding in satiated male Wistar rats in the early light phase [12]. The lowest dose of $\mathrm{H} 3$ to elicit a significant orexigenic 
response when administered iPVN was seen in the picomolar range at $18 \mathrm{pmol}$, similar to other orexigenic peptides such as ghrelin and NPY.

The aim of this study was to investigate the maximum acute orexigenic effect of iPVN H3 by using higher doses compared to earlier studies, and to establish whether acute iPVN administration of $\mathrm{H} 3$ may play a role in the regulation of energy expenditure and the hypothalamo-pituitary thyroid (HPT) axis. We also wished to examine the effects of chronic (7 days), repeated iPVN administration of $\mathrm{H} 3$ on food intake, body weight, energy expenditure and the hypothalamo-pituitary axes. 


\section{Research design and Methods}

\section{Materials}

Human relaxin-3 (H3) was purchased from Phoenix Pharmaceuticals (Belmont, CA) and synthesized by the company using solid phase synthesis. Reagents for hypothalamic explant studies were supplied by BDH (Poole, Dorset, UK).

\section{Animal studies}

Male Wistar rats (Specific pathogen free, Charles River, UK) weighing 250-300g were maintained in individual cages for all studies except hypothalamic explant studies where male Wistar rats, $150-200 \mathrm{~g}$, were maintained in cages of five. All animals were kept under controlled temperature $\left(21-23^{\circ} \mathrm{C}\right)$ and light $(12 \mathrm{~h}$ light, $12 \mathrm{~h}$ dark, lights on at $0700 \mathrm{~h}$ ) with ad libitum access to food (pelleted RM1 chow diet, SDS, UK) and water unless otherwise stated. All procedures undertaken were approved under the British Home Office Animals (Scientific Procedures) Act 1986 (project license 70/5516).

\section{Intra-paraventricular cannulation and injection}

Male Wistar rats underwent unilateral intra-paraventricular nuclear (iPVN)

cannulation 7-10 days before feeding studies and were habituated to regular handling and injection, as previously described [13]. A $1 \mu \mathrm{iPVN}$ injection was administered over 1 minute via a stainless steel 31-gauge injector, placed in and projecting $1 \mathrm{~mm}$ below the end of the cannula. Spread of a $1 \mu 1$ injection into the PVN is reported to be limited to $1 \mathrm{~mm}^{3}$ [14]. All compounds were dissolved in vehicle (10\% acetonitrile in $0.9 \%$ saline) and studies were performed in satiated rats in the early light phase (0900 $-1000 \mathrm{~h}$ ) unless otherwise stated. Cannula position was verified histologically at the 
end of the study [13]. Only those animals with correct cannula placement were included in the data analysis.

Study 1 : Acute effects of high dose iPVN relaxin-3 administration on food intake Male Wistar rats $(\mathrm{n}=10-12)$ received an iPVN injection of vehicle or increasing doses of H3 (180pmol, 540pmol and 1620pmol). Following injection, animals were returned to their home cage with pre-weighed chow. Food intake was measured at 1, 2, 4, 8, and 24 hours post-injection.

Study 2: Acute effects of high dose iPVN relaxin-3 administration on plasma TSH Male Wistar rats $(\mathrm{n}=9-11)$ received a single injection of vehicle or H3 (540pmol). Fifteen or 30 minutes following administration, animals were killed by decapitation and plasma was collected into plastic lithium heparin tubes containing $4200 \mathrm{KIU}$ aprotinin (Bayer, Haywards Heath, UK). Plasma was separated by centrifugation, frozen and stored at $-70^{\circ} \mathrm{C}$ until radioimmunoassay (RIA) for thyroid stimulating hormone (TSH).

Study 3: Acute effects of iPVN relaxin-3 administration on measurements of energy expenditure

Metabolic parameters were measured following a single iPVN injection of vehicle or H3 (180 pmol) ( $\mathrm{n}=12$ per group) in the early light phase $(0900 \mathrm{~h}-1000 \mathrm{~h})$ by indirect calorimetry using an open-circuit Oxymax system of the Comprehensive Lab Animal Monitoring System (CLAMS; Columbus instruments, Columbus, OH). All rats were acclimatized to the cages for three days before the injection of vehicle or H3. Animals were maintained at $24^{\circ} \mathrm{C}$ with a $12: 12 \mathrm{hr}$ light-dark cycle (light period 
0700-1900). Food (ground RM1 chow) and water were freely available and food was automatically weighed at 30 minute intervals. Exhaust air from each air tight chamber was sampled for one minute at 30 minute intervals. $\mathrm{O}_{2}$ consumption was normalised to body weight to the power of 0.75 . The ambulatory activity of each animal was assessed simultaneously using the optical beam technique by an Opto M3 (Columbus Instruments).

Study 4: Effects of 7 day repeated iPVN administration of relaxin-3 on food intake and body weight

Male Wistar rats were randomized to one of three experimental groups $(\mathrm{n}=8-11): 1)$ vehicle - animals received twice daily injections of vehicle (0900h and 1900h) for 7 days with ad libitum access to food and water, 2) H3 ad libitum fed group - rats received twice daily injections of $\mathrm{H} 3$ (180pmol) for 7 days with ad libitum access to food and water, 3) H3 pair-fed group - rats received twice daily injections of H3 (180pmol) for 7 days and were pair-fed to the median food intake of the vehicle group in the equivalent period 24 hours previously.

Body weight was measured daily at $0900 \mathrm{~h}$. Food was weighed immediately before and 1 hour after each injection to allow calculation of cumulative food intake and food intake in the first hour in response to each injection. A final food and body weight measurement was taken at $0900 \mathrm{~h}$ on day 8 .

Study 5: Effects of 7 day repeated iPVN administration of relaxin-3 on fat mass, plasma hormones and UCP-1 expression 
Rats from study 4 were killed by decapitation on day 8 at $0900-1000 \mathrm{~h}$, and plasma was collected as for study 2. Plasma was assayed for pituitary hormones including TSH, prolactin, luteinizing hormone $(\mathrm{LH})$ and growth hormone $(\mathrm{GH})$, as well as corticosterone and leptin. Weights of epidydimal fat pads (white adipose tissue or WAT), interscapular brown adipose tissue (BAT), adrenals and testes were measured.

Expression of UCP-1 mRNA in interscapular brown adipose tissue was assessed by northern blot. RNA was extracted from BAT using Tri-reagent (Helena Biosciences, Sunderland, UK) according to the manufacturer's protocol. Northern Blot analysis was performed as previously described [15]. The filter was exposed to phosphoscreen overnight prior to quantification of UCP-1 mRNA expression using ImageQuant software (GE Healthcare, Chalfont St Giles, UK). Blots were reprobed with oligo(dT) $)_{12-18}$ to enable differences in RNA loading to be corrected.

Study 6: Effect of relaxin-3 on in vitro release of hypothalamic neuropeptides The static incubation system was used as previously described [16]. After an initial $2 \mathrm{~h}$ equilibration period, the hypothalami were incubated for $45 \mathrm{~min}$ in $600 \mu \mathrm{laCSF}$ (basal period) before being challenged with $\mathrm{H} 3(10 \mathrm{nM})$ for 45 minutes. Finally, the viability of the tissue was verified by a $45 \mathrm{~min}$ exposure to $56 \mathrm{mM} \mathrm{KCl}$. At the end of each period, the aCSF was removed and frozen at $-20^{\circ} \mathrm{C}$ until measurement of hypothalamic hormones [Thyrotropin releasing hormone (TRH), Somatotropin release inhibitory factor (SRIF)] by RIA.

\section{Radioimmunoassays}


Plasma pituitary hormone concentrations were assayed using reagents and methods provided by the National Institute of Diabetes and Digestive Diseases and the National Hormone and Peptide Program (Dr. A. Parlow, Torrance, CA), as previously described [16-19]. Hypothalamic hormones (SRIF, TRH) were assayed using inhouse radioimmunoassays (RIAs) as previously described [20; 21]. Leptin (Linco Research, Inc, St. Charles, MO), corticosterone (MP Biomedicals, Irvine, CA) and free T3 (EuroDPC Ltd, Gwynedd, UK) were measured using commercially available RIA kits.

\section{Statistical analysis}

Results are shown as mean \pm S.E.M. Data from acute feeding studies, plasma hormone levels and neuropeptide expression were compared by ANOVA with posthoc LSD test (Systat, Evanston, IL). Cumulative food intake and body weight data from the repeated injection study was analyzed using marginal models with exchangeable correlation matrix and robust standard errors (Stata 8, Statacorp LP, TX). Energy expenditure parameters between control and treated group were analyzed using the Mann-Whitney U test (Stata 9, Statacorp, TX, USA). Hypothalamic explant data was compared by paired Student $t$-test between control and treated groups. In all cases, $\mathrm{p}<0.05$ was considered to be statistically significant. 


\section{Results}

Study 1 : Acute effects of high dose iPVN relaxin-3 administration on food intake A single iPVN injection of high dose human relaxin-3 (H3) to satiated male Wistar rats significantly increased food intake in the first hour post-administration at all doses [0-1 hour food intake: $0.4 \pm 0.1 \mathrm{~g}$ (vehicle) vs $1.6 \pm 0.5 \mathrm{~g}(180 \mathrm{pmol} \mathrm{H} 3), 2.4 \pm$ $0.5 \mathrm{~g}$ (540 pmol H3), and $2.2 \pm 0.5 \mathrm{~g}(1620 \mathrm{pmol} \mathrm{H} 3), \mathrm{p}<0.05$ for all doses vs vehicle, $n=10-12]$ (Figure 1). The effect was also significant at these doses in the second hour post-injection [1-2 hour food intake: $0.2 \pm 0.1 \mathrm{~g}$ (vehicle) vs $2.2 \pm 0.7 \mathrm{~g}$ (180 pmol H3), $2.6 \pm 0.4 \mathrm{~g}(540 \mathrm{pmol} \mathrm{H} 3)$, and $2.1 \pm 0.5 \mathrm{~g}(1620 \mathrm{pmol} \mathrm{H} 3), \mathrm{p}<0.05$ for all doses vs vehicle]. There was no difference in interval food intake between control and treated groups at later time points. Cumulative food intake was significantly increased 2, 4 and 8 hours post iPVN administration of 180, 540 and 1620 pmol H3 [0-8 hour food intake: $2.7 \pm 0.7 \mathrm{~g}$ (vehicle) vs $5.6 \pm 1.0 \mathrm{~g}$ (180 pmol $\mathrm{H} 3), 6.3 \pm 0.6 \mathrm{~g}(540 \mathrm{pmol} \mathrm{H} 3)$, and $6.9 \pm 0.6 \mathrm{~g}(1620 \mathrm{pmol} \mathrm{H} 3), \mathrm{p}<0.05$ for all doses vs vehicle].

Study 2: Acute effects of high dose iPVN relaxin-3 administration on thyroid stimulating hormone IntraPVN administration of $\mathrm{H} 3$ (540pmol) significantly reduced plasma thyroid stimulating hormone (TSH) at both 15 and 30 minutes following injection compared to vehicle $[2.46 \pm 0.34 \mathrm{ng} / \mathrm{ml}$ (vehicle) vs $1.58 \pm 0.18 \mathrm{ng} / \mathrm{ml}(\mathrm{H} 3)$ at $15 \mathrm{~min}, \mathrm{p}<0.05 \mathrm{vs}$ vehicle and $3.88 \pm 0.44 \mathrm{ng} / \mathrm{ml}$ (vehicle) vs $2.48 \pm 0.26 \mathrm{ng} / \mathrm{ml}(\mathrm{H} 3)$ at $30 \mathrm{~min}, \mathrm{p}<0.05 \mathrm{vs}$ vehicle, $n=9-11]$ (Figure 2). 
Study 3: Acute effects of iPVN relaxin-3 administration on measurements of energy expenditure

A single iPVN injection of $\mathrm{H} 3$ (180pmol) did not have any effect on $\mathrm{VO}_{2}$ [mean $\mathrm{VO}_{2}$ consumption for the first 8 hours post-injection: $1006.6 \pm 50.3 \mathrm{ml} / \mathrm{kg}^{0.75} / \mathrm{hr}$ (vehicle) vs $\left.1059.2 \pm 48.4 \mathrm{ml} / \mathrm{kg}^{0.75} / \mathrm{hr}(\mathrm{H} 3)\right]$. RER and physical activity did not differ when compared to vehicle. As previously observed, a significant increase in food intake was seen in the first hour after $\mathrm{H} 3$ administration (data not shown).

Study 4: Effects of 7 day repeated iPVN administration of relaxin-3 on food intake and body weight

At the onset of the study, there was no difference in body weight between the three experimental groups (day 1 body weight: $342 \pm 9 \mathrm{~g}$, [vehicle] vs $365 \pm 7 \mathrm{~g}$, [H3 ad libitum fed] vs $352 \pm 10 \mathrm{~g}$ [H3 pair-fed]). Twenty-four hour food intake in the H3 ad libitum fed group was significantly higher compared to vehicle at the beginning and end of the study [day $1: 22.6 \pm 3.0 \mathrm{~g}$ (vehicle) vs $33.6 \pm 3.6 \mathrm{~g}(\mathrm{H} 3), \mathrm{p}<0.05$, and day 7: $32.6 \pm 1.0 \mathrm{~g}$ (vehicle) vs $38.4 \pm 0.9 \mathrm{~g}(\mathrm{H} 3), \mathrm{p}<0.05, \mathrm{n}=8-11]$ (Figure $3 \mathrm{~A})$ IntraPVN injection of 180 pmol H3 stimulated feeding during the first hour following injection in both the early light phase and early dark phase on each study day. There was no attenuation in the acute orexigenic response in the early light phase on repeated administration up to 7 days [0-1 hour food intake: $0.3 \pm 0.2 \mathrm{~g}$ (vehicle) and $2.3 \pm 0.6 \mathrm{~g}(\mathrm{H} 3)($ day 1$)$ vs $0.7 \pm 0.3 \mathrm{~g}$ (vehicle) and $3.0 \pm 0.7 \mathrm{~g}(\mathrm{H} 3)($ day 7$), \mathrm{p}<0.05$ vs vehicle] (Figure 3B). Trend analysis of cumulative food intake revealed that over the period of the study the H3-treated ad libitum fed group ate significantly more than vehicle-treated ad libitum fed controls $[211.8 \pm 7.1 \mathrm{~g}$ (vehicle) vs $261.6 \pm 6.7 \mathrm{~g}$ (H3), $\mathrm{p}<0.05$ vs vehicle at the beginning of day 7] (Figure 4). There was a trend towards 
greater cumulative body weight change in the H3-treated ad libitum fed group compared to vehicle-treated animals but this did not reach statistical significance on day $7[8 \pm 4 \mathrm{~g}$ (vehicle) vs $13 \pm 4 \mathrm{~g}(\mathrm{H} 3)]$. There was no difference in cumulative body weight change between the H3 pair-fed group compared to vehicle at day 7 [ $8 \pm$ $4 \mathrm{~g}$ (vehicle) vs $2 \pm 2 \mathrm{~g}$ (H3 pair-fed)], but body weight change was significantly reduced in the $\mathrm{H} 3$ pair-fed compared to $\mathrm{H} 3$-treated ad libitum fed animals $[2 \pm 2 \mathrm{~g}$ (H3 pair-fed) vs $13 \pm 4 \mathrm{~g}$ (H3 ad libitum fed), $\mathrm{p}<0.05]$.

Study 5: Effects of 7 day repeated iPVN administration of relaxin-3 on fat mass, UCP-1 expression and plasma hormones

Following an iPVN injection of H3 (180 pmol) or vehicle twice a day for 7 days, there was no difference in interscapular BAT weight $[0.54 \pm 0.03 \mathrm{~g}$ (vehicle) vs 0.61 $\pm 0.04 \mathrm{~g}$ (H3 ad libitum fed) vs $0.56 \pm 0.04 \mathrm{~g}$ (H3 pair-fed)]. There was no difference observed in interscapular BAT UCP-1 mRNA expression between the experimental groups [12.83 \pm 1.80 (vehicle) vs $14.28 \pm 2.36$ (H3 ad libitum fed) vs $12.42 \pm 2.65$ (H3 pair-fed), units are arbitrary] (Table 1).

There was no difference in epididymal fat mass between the 3 groups $[3.35 \pm 0.27 \mathrm{~g}$ (vehicle) vs $4.05 \pm 0.32 \mathrm{~g}$ (H3 ad libitum fed) vs $3.31 \pm 0.23 \mathrm{~g}$ (H3 pair-fed)]. However, plasma leptin was significantly elevated in the H3 ad libitum fed group compared to vehicle, [2.24 $\pm 0.40 \mathrm{ng} / \mathrm{ml}$ (vehicle) vs $3.67 \pm 0.55 \mathrm{ng} / \mathrm{ml}$ (H3 ad libitum fed) vs $2.05 \pm 0.49$ (H3 pair-fed), $\mathrm{p}<0.05 \mathrm{H} 3$ ad libitum fed vs vehicle, $\mathrm{n}=8-11]$ (Table 1). 
A significant suppression of plasma TSH was observed in both the H3 ad libitum fed group and H3 pair-fed group when compared to vehicle-treated animals [3.93 \pm 0.53 $\mathrm{ng} / \mathrm{ml}$ (vehicle) vs $2.44 \pm 0.30 \mathrm{ng} / \mathrm{ml}$ (H3 ad libitum fed) vs $2.59 \pm 0.36 \mathrm{ng} / \mathrm{ml}(\mathrm{H} 3$ pair-fed), $\mathrm{p}<0.05 \mathrm{H} 3$ ad libitum fed vs vehicle and $\mathrm{H} 3$ pair-fed vs vehicle, $\mathrm{n}=8-11$ ] (Figure 5). There was no difference in plasma free $\mathrm{T} 3$ levels between the groups $[1.24 \pm 0.14 \mathrm{pg} / \mathrm{ml}$ (vehicle) vs $1.53 \pm 0.14 \mathrm{pg} / \mathrm{ml}$ (H3 ad libitum fed) vs $1.76 \pm 0.22$ $\mathrm{pg} / \mathrm{ml}$ (H3 pair-fed)].

There were no differences in adrenal and testicular weight between the treatment groups and no differences in plasma prolactin, corticosterone, $\mathrm{LH}$ and $\mathrm{GH}$ plasma levels amongst the three groups (data not shown).

Study 6: Effect of relaxin-3 on in vitro release of hypothalamic neuropeptides To examine the possible central mediators of the effects of $\mathrm{H} 3$ on plasma TSH, hypothalamic release of neuropeptides known to regulate thyroid function (TRH and SRIF) was determined in response to $\mathrm{H} 3$ relaxin in vitro. TRH was significantly reduced by $10 \mathrm{nM} \mathrm{H} 3[50.6 \pm 7.2 \mathrm{fmol} / \mathrm{explant}$ (basal) vs $39.6 \pm 7.1 \mathrm{fmol} / \mathrm{explant}$ (H3), $\mathrm{p}<0.05$ ] whilst SRIF release increased significantly in response to $10 \mathrm{nM} \mathrm{H} 3$ $[62.0 \pm 5.3 \mathrm{fmol} /$ explant (basal) vs $87.5 \pm 9.4$ fmol/explant $(\mathrm{H} 3), \mathrm{p}<0.05]$ 


\section{Discussion}

Little is known of the biological actions of relaxin-3. We have recently demonstrated that relaxin-3 may play a role in the regulation of food intake [12]. The aim of the current study was to investigate the maximum orexigenic response elicited by H3. Acute iPVN administration of high dose $\mathrm{H} 3$ significantly increased food intake in the first and second hour post-injection in satiated rats (180-1620 pmol), and cumulatively up to 8 hours following injection. The maximum orexigenic response was achieved by a dose of 540 pmol H3 with no further increase at the higher dose of 1620 pmol H3.

Several peptides, such as NPY and AgRP, which stimulate food intake also alter energy expenditure [22-24]. We therefore examined the acute effects of $\mathrm{H} 3$ on both plasma TSH and other parameters of energy expenditure $\left(\mathrm{VO}_{2}, \mathrm{RER}\right.$ and ambulatory activity). Acute iPVN administration of $\mathrm{H} 3$ significantly suppressed plasma TSH at 15 and 30 minutes post injection, suggesting that $\mathrm{H} 3$ may play a role in decreasing energy expenditure by suppression of the thyroid axis. However, there were no differences in $\mathrm{VO}_{2}$, RER or physical activity when the effects of acute iPVN administration of $\mathrm{H} 3$ were examined in the CLAMS system. It is possible that small differences in energy expenditure exist which are below the detection limit of this system. Energy expenditure is comprised of several components: thyroid hormone activity, BAT activity, activation of the sympathetic nervous system and both locomotor and non-locomotor muscle activity. Thus, although TSH was suppressed, there may be compensation by other components resulting in no overall change in energy expenditure in response to $\mathrm{H} 3$. 
Repeated iPVN administration of H3 significantly increased food intake throughout the 7 day study. One hour food intake following injection was significantly increased in the first hour following administration in the early light phase on both day 1 and day 7 with no evidence of tachyphylaxis. Repeated 7-day iPVN administration of $\mathrm{H3}$ significantly increased cumulative food intake in the ad libitum fed, H3 treated animals. However, although cumulative body weight change was increased in this group, this failed to reach significance by day 7 of the study. Plasma leptin was significantly elevated in ad libitum fed H3 treated animals and although epididymal fat pad weight was higher in the ad libitum fed $\mathrm{H} 3$ treated animals this did not achieve statistical significance. This elevation in plasma leptin suggests that whole body adipose tissue may be increased and it would be interesting to examine the body composition of chronic H3-treated animals in more detail. However, it is also possible that central $\mathrm{H} 3$ administration results in a stimulation of leptin secretion. Since the efficacy of H3 to increase food intake did not diminish over the course of the study, it is possible a significant change in body weight may be achieved by administration of higher or more frequent doses of $\mathrm{H} 3$, by bilateral injection or with a longer study period.

There was no difference in cumulative body weight change between the vehicle treated and the H3-treated animals pair-fed to the food intake of the vehicle. This would suggest that there was no significant effect of $\mathrm{H} 3$ on energy expenditure and is in keeping with the results of acute $\mathrm{H} 3$ administration on metabolic parameters. In keeping with this, there was no difference in BAT UCP-1 mRNA expression between the treatment groups. There was however, a significant difference in cumulative body weight change between ad libitum fed $\mathrm{H} 3$ treated and $\mathrm{H} 3$ pair-fed animals by the end 
of day 7. Again, plasma TSH was significantly suppressed by repeated iPVN injection of H3. In keeping with this, a suppression of TRH release and an increase in SRIF release was seen from hypothalamic slices following administration of $10 \mathrm{nM}$ H3. The sympathetic nervous system (SNS) interacts closely with the HPT axis to regulate both energy expenditure and thyroid gland responsiveness to TSH. It is possible that suppression of TSH might be accompanied by modulation of the SNS both to normalize energy expenditure and normalize plasma T3 [25]. The effects of repeated $\mathrm{H} 3$ administration differ from those of other orexigenic peptides such as NPY, AgRP and ghrelin. NPY, AgRP and ghrelin significantly increase food intake with repeated administration however, they also decrease energy expenditure thereby contributing to body weight gain.

In conclusion, we have demonstrated that acute iPVN administration of high dose $\mathrm{H} 3$ increases food intake, suppresses plasma levels of TSH but does not alter energy expenditure. We have shown for the first time that repeated iPVN administration of $\mathrm{H} 3$ is effective for 7 days and increases cumulative food intake and plasma leptin, but does not significantly increase body weight. Repeated iPVN H3 treatment results in a suppression of plasma TSH without alteration in plasma T3. This effect is independent of food intake, since it also occurs in pair-fed animals. The longer term effects of $\mathrm{H} 3$, either by virally-mediated over-expression or in transgenic animals, on body weight, energy expenditure and the HPT axis would be of great interest.

\section{Acknowledgements}

The authors wish to express their thanks to the hypothalamic group for their assistance with the in vivo experiments and the MRC for funding this programme of 
research. They wish to particularly thank Arshia Sajedi and Lisa Broadhead for their help with energy expenditure studies. B.M.M. is an MRC research fellow. S.A.S. is a MRC clinician scientist. J.S.M is supported by a Biotechnology and Biological Sciences Research Council / Inpharmatica Case studentship. E.L.T. is supported by a Biotechnology and Biological Sciences Research Council / Glaxo Smithkline Case studentship. M.P. is supported by the Biotechnology and Biological Sciences Research Council. 
Reference List

[1] P.Hudson, J.Haley, M.John, M.Cronk, R.Crawford, J.Haralambidis, G.Tregear, J.Shine, H.Niall, Structure of a genomic clone encoding biologically active human relaxin Nature 301, (1983) 628-631.

[2] R.A.Bathgate, C.S.Samuel, T.C.Burazin, S.Layfield, A.A.Claasz, I.G.Reytomas, N.F.Dawson, C.Zhao, C.Bond, R.J.Summers, L.J.Parry, J.D.Wade, G.W.Tregear, Human relaxin gene 3 (H3) and the equivalent mouse relaxin (M3) gene. Novel members of the relaxin peptide family J.Biol.Chem. 277, (2002) 1148-1157.

[3] T.C.Burazin, R.A.Bathgate, M.Macris, S.Layfield, A.L.Gundlach, G.W.Tregear, Restricted, but abundant, expression of the novel rat gene-3 (R3) relaxin in the dorsal tegmental region of brain J.Neurochem. 82, (2002) 15531557.

[4] M.Goto, L.W.Swanson, N.S.Canteras, Connections of the nucleus incertus J.Comp Neurol. 438, (2001) 86-122.

[5] M.Tanaka, N.Iijima, Y.Miyamoto, S.Fukusumi, Y.Itoh, H.Ozawa, Y.Ibata, Neurons expressing relaxin 3/INSL 7 in the nucleus incertus respond to stress Eur.J.Neurosci. 21, (2005) 1659-1670.

[6] C.Liu, E.Eriste, S.Sutton, J.Chen, B.Roland, C.Kuei, N.Farmer, H.Jornvall, R.Sillard, T.W.Lovenberg, Identification of relaxin-3/INSL 7 as an endogenous ligand for the orphan G-protein-coupled receptor GPCR135 J.Biol.Chem. 278, (2003) 50754-50764.

[7] C.Liu, J.Chen, S.Sutton, B.Roland, C.Kuei, N.Farmer, R.Sillard, T.W.Lovenberg, Identification of relaxin-3/INSL7 as a ligand for GPCR142 J.Biol.Chem. 278, (2003) 50765-50770.

[8] J.Chen, C.Kuei, S.W.Sutton, P.Bonaventure, D.Nepomuceno, E.Eriste, R.Sillard, T.W.Lovenberg, C.Liu, Pharmacological Characterization of Relaxin-3/INSL7 Receptors GPCR135 and GPCR142 from Different Mammalian Species J.Pharmacol.Exp.Ther. 312, (2005) 83-95.

[9] S.Y.Hsu, K.Nakabayashi, S.Nishi, J.Kumagai, M.Kudo, O.D.Sherwood, A.J.Hsueh, Activation of orphan receptors by the hormone relaxin Science 295, (2002) 671-674.

[10] S.Sudo, J.Kumagai, S.Nishi, S.Layfield, T.Ferraro, R.A.Bathgate, A.J.Hsueh, $\mathrm{H} 3$ relaxin is a specific ligand for LGR7 and activates the receptor by interacting with both the ectodomain and the exoloop 2 J.Biol.Chem. $278,(2003) 7855-7862$. 
[11] T.C.Burazin, K.J.Johnson, S.Ma, R.A.Bathgate, G.W.Tregear, A.L.Gundlach, Localization of LGR7 (Relaxin Receptor) mRNA and Protein in Rat Forebrain: Correlation with Relaxin Binding Site Distribution Ann.N.Y.Acad.Sci. 1041, (2005) 205-210.

[12] B.M.McGowan, S.A.Stanley, K.L.Smith, N.E.White, M.M.Connolly, E.L.Thompson, J.V.Gardiner, K.G.Murphy, M.A.Ghatei, S.R.Bloom, Central relaxin-3 administration causes hyperphagia in male Wistar rats Endocrinology 146, (2005) 3295-3300.

[13] A.M.Wren, C.J.Small, C.R.Abbott, W.S.Dhillo, L.J.Seal, M.A.Cohen, R.L.Batterham, S.Taheri, S.A.Stanley, M.A.Ghatei, S.R.Bloom, Ghrelin causes hyperphagia and obesity in rats Diabetes 50, (2001) 2540-2547.

[14] H.Ward, J.Gardiner, W.M.Kong, K.Murphy, S.Bloom, Distribution of fluorescence following injection of recombinant adeno-associated virus encoding green fluorescent protein into the paraventricular nucleus Neuroendocrinology 77, (2003) 100-104.

[15] W.S.Dhillo, C.J.Small, J.V.Gardiner, G.A.Bewick, E.J.Whitworth, P.H.Jethwa, L.J.Seal, M.A.Ghatei, J.P.Hinson, S.R.Bloom, Agouti-related protein has an inhibitory paracrine role in the rat adrenal gland Biochem.Biophys.Res.Commun. 301, (2003) 102-107.

[16] S.A.Stanley, C.J.Small, M.S.Kim, M.M.Heath, L.J.Seal, S.H.Russell, M.A.Ghatei, S.R.Bloom, Agouti related peptide (Agrp) stimulates the hypothalamo pituitary gonadal axis in vivo \& in vitro in male rats Endocrinology 140, (1999) 5459-5462.

[17] M.Desai, C.D.Byrne, K.Meeran, N.D.Martenz, S.R.Bloom, C.N.Hales, Regulation of hepatic enzymes and insulin levels in offspring of rat dams fed a reduced-protein diet Am.J.Physiol 273, (1997) G899-G904.

[18] J.F.Todd, C.J.Small, K.O.Akinsanya, S.A.Stanley, D.M.Smith, S.R.Bloom, Galanin is a paracrine inhibitor of gonadotroph function in the female rat Endocrinology 139, (1998) 4222-4229.

[19] M.S.Kim, C.J.Small, S.A.Stanley, D.G.Morgan, L.J.Seal, W.M.Kong, C.M.Edwards, S.Abusnana, D.Sunter, M.A.Ghatei, S.R.Bloom, The central melanocortin system affects the hypothalamo-pituitary thyroid axis and may mediate the effect of leptin J.Clin.Invest 105, (2000) 10051011.

[20] K.O.Akinsanya, M.A.Ghatei, S.R.Bloom, Gonadal steroids regulate rat anterior pituitary levels of TSH-releasing hormone- and pyroglutamyl-glutamylproline amide-like immunoreactivity Endocrinology 136, (1995) 734740.

[21] A.M.Wren, C.J.Small, C.V.Fribbens, N.M.Neary, H.L.Ward, L.J.Seal, M.A.Ghatei, S.R.Bloom, The hypothalamic mechanisms of the 
hypophysiotropic action of ghrelin Neuroendocrinology 76, (2002) 316324.

[22] C.J.Small, Y.L.Liu, S.A.Stanley, I.P.Connoley, A.Kennedy, M.J.Stock, S.R.Bloom, Chronic CNS administration of Agouti-related protein (Agrp) reduces energy expenditure Int.J.Obes.Relat Metab Disord. 27, (2003) 530-533.

[23] C.J.Billington, J.E.Briggs, M.Grace, A.S.Levine, Effects of intracerebroventricular injection of neuropeptide $\mathrm{Y}$ on energy metabolism Am.J.Physiol 260, (1991) R321-R327.

[24] M.Egawa, H.Yoshimatsu, G.A.Bray, Neuropeptide Y suppresses sympathetic activity to interscapular brown adipose tissue in rats Am.J.Physiol 260, (1991) R328-R334.

[25] J.B.Young, M.E.Burgi-Saville, U.Burgi, L.Landsberg, Sympathetic nervous system activity in rat thyroid: potential role in goitrogenesis Am.J.Physiol Endocrinol.Metab 288, (2005) E861-E867. 


\section{Legends}

\section{Figure 1:}

Effect of acute iPVN administration of H3 (180-1620 pmol) on 1 hour food intake in satiated male Wistar rats in the early light phase. $*=\mathrm{p}<0.05$ vs vehicle, $\mathrm{n}=10-12$.

\section{Figure 2:}

Effect of acute iPVN administration of H3 (540 pmol) on plasma TSH at 15 and 30 minutes post-injection. $*=\mathrm{p}<0.05$ vs vehicle, $\mathrm{n}=9-11$.

\section{Figure 3:}

A) Effect of repeated iPVN administration of vehicle or $\mathrm{H} 3$ (180 pmol/injection) in ad libitum fed rats on 24 hour food intake on day 1 and day $7, *=p<0.05$ vs vehicle, $\mathrm{n}=8-11$.

B) Effect of repeated iPVN administration of vehicle or H3 (180 pmol/injection) in ad libitum fed rats on 1 hour food intake in the early light phase on day 1 and day $7, * \mathrm{p}$ $<0.05$ vs vehicle, $\mathrm{n}=8-11$.

\section{Figure 4:}

Cumulative food intake after repeated iPVN administration of vehicle, $\mathrm{H} 3$ in ad libitum fed rats (180 pmol/injection) or $\mathrm{H} 3$ in pair-fed (PF) rats for 7 days. White circles $=$ vehicle; plus sign $=\mathrm{H} 3$ ad libitum fed group; black triangle $=\mathrm{H} 3$ pair fed group, $*=\mathrm{p}<0.05$ vs vehicle, $\mathrm{n}=8-11$. 


\section{Figure 5:}

Effect of repeated iPVN administration of vehicle, H3 in ad libitum fed rats (180 pmol/injection) or $\mathrm{H} 3$ in pair-fed ( $\mathrm{PF}$ ) for 7 days on plasma TSH, ${ }^{*} \mathrm{p}<0.05$ vs vehicle, $\mathrm{n}=8-11$.

\section{Table 1:}

The effect of 7-day repeated iPVN administration of vehicle or H3 (180pmol) on epididymal fat pad weight (WAT), BAT weight, UCP-1 mRNA expression, plasma leptin, plasma TSH and free T3, $\mathrm{n}=8-11$. 
Figure 1

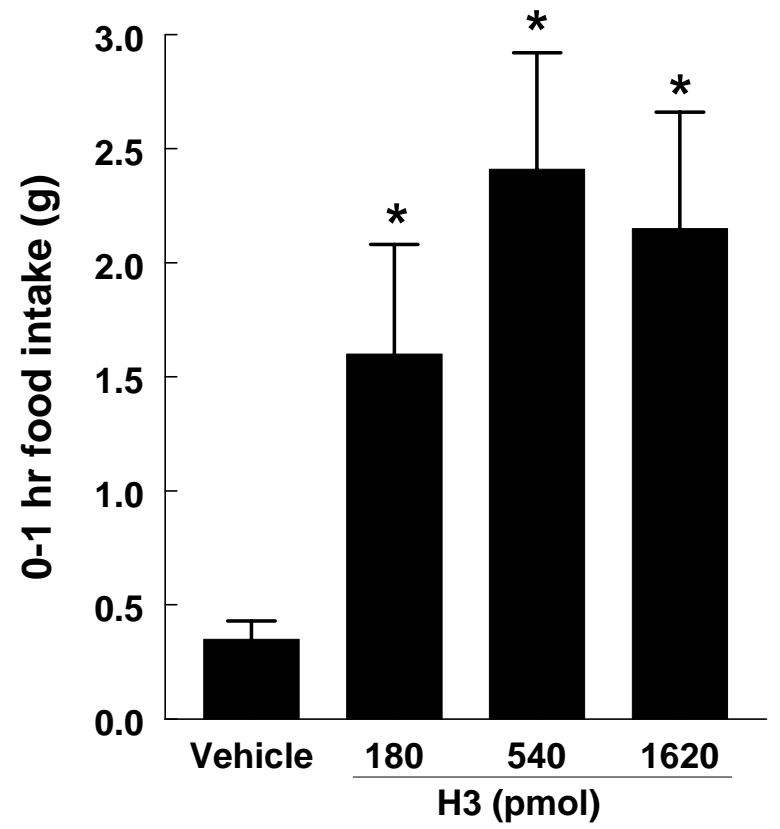


Figure 2

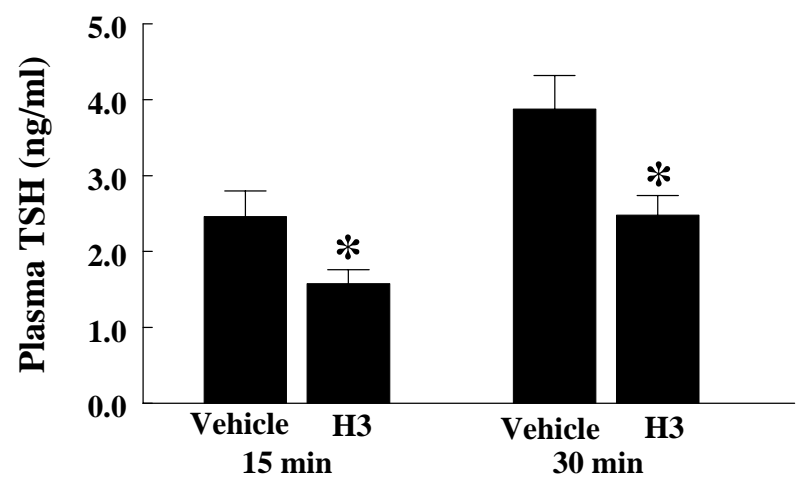


Figure 3A

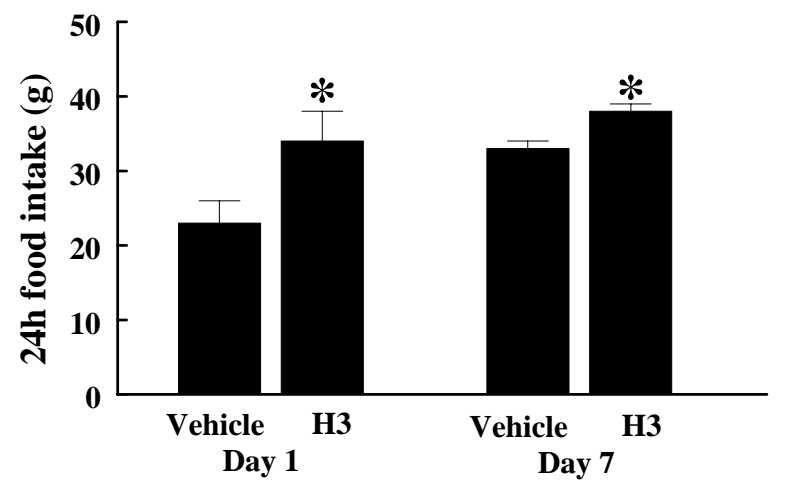

Figure 3B

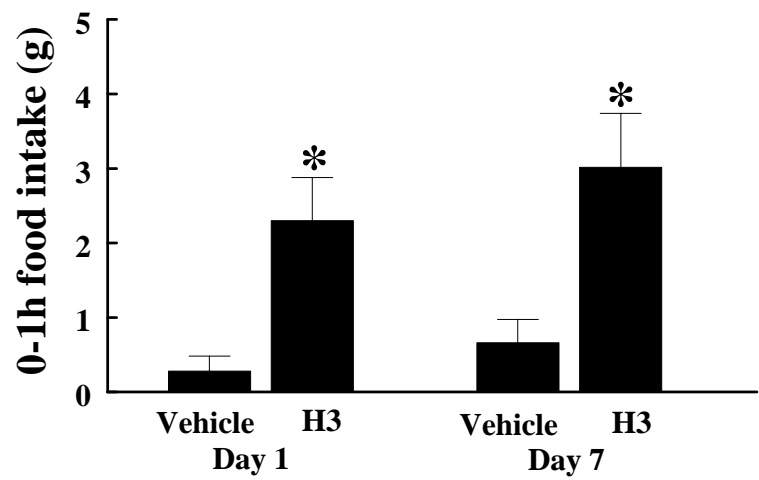


Figure 4

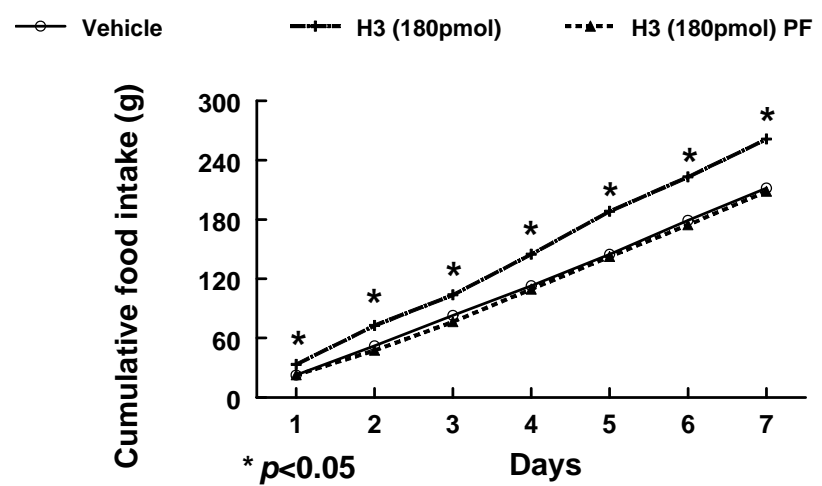


Figure 5

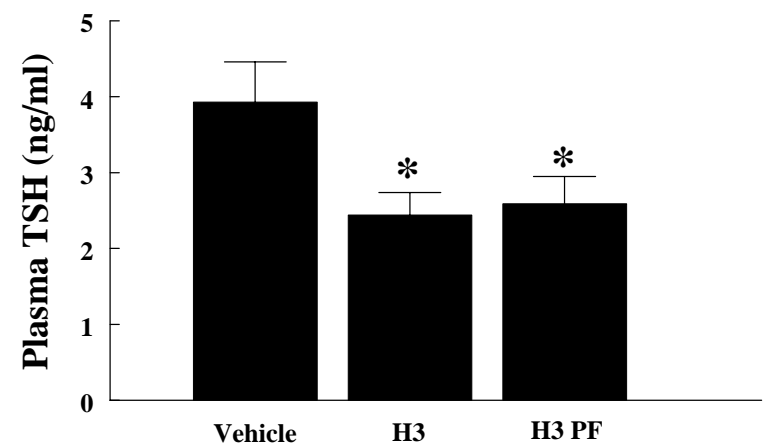


Table 1:

\begin{tabular}{|c|c|c|c|}
\hline & Vehicle & H3 (180 pmol) & H3 PF (180 pmol) \\
\hline WAT $(\mathrm{g})$ & $3.35 \pm 0.27$ & $4.05 \pm 0.32$ & $3.31 \pm 0.23$ \\
\hline Leptin $(\mathrm{ng} / \mathrm{ml})$ & $2.24 \pm 0.40$ & $3.67 \pm 0.55^{*}$ & $2.05 \pm 0.49$ \\
\hline BAT $(\mathrm{g})$ & $0.54 \pm 0.03$ & $0.61 \pm 0.04$ & $0.56 \pm 0.04$ \\
\hline $\begin{array}{c}\text { UCP-1 mRNA } \\
(\mathrm{U})\end{array}$ & $12.83 \pm 1.80$ & $14.28 \pm 2.36$ & $12.42 \pm 2.65$ \\
\hline TSH $(\mathrm{ng} / \mathrm{ml})$ & $3.93 \pm 0.53$ & $2.44 \pm 0.30^{*}$ & $2.59 \pm 0.36^{*}$ \\
\hline Free T3 $(\mathrm{pg} / \mathrm{ml})$ & $1.24 \pm 0.14$ & $1.53 \pm 0.14$ & $1.76 \pm 0.22$ \\
\hline
\end{tabular}

Vehicle - vehicle-treated, ad libitum fed; H3 - H3-treated, ad libitum fed; H3 PF H3-treated, pair-fed to median food intake of vehicle-treated animals. Data shown as mean \pm SEM. $*=p<0.05$ vs vehicle 